\title{
Stepwise Cerebral Ischemia Causes Disturbances in Mitochondrial Respiration of Neurons in the Cerebral Cortex of Rats
}

\author{
Bon L.I ${ }^{1 *}$, Maksimovich N.Ye. ${ }^{2}$, Dremza I.K. ${ }^{3}$ and Lychkovskaya Maria A. ${ }^{4}$
}

${ }^{1}$ Candidate of Biological Science, associate professor of Chair of pathological physiology of the name of D.A. Maslakov, Education Establishment "Grodno State Medical University".

${ }^{2}$ Doctor of Medical Science, professor, head of Chair of pathological physiology of the name of D.A. Maslakov, Education Establishment "Grodno State Medical University";

${ }^{3}$ Candidate of Biological Sciences, Associate Professor, Associate Professor of the Department of Pathological Physiology named after D.A. Maslakov, Grodno State University, Belarus.

${ }^{4} \mathrm{~A}$ fourth-year student of the group number 7 of faculty of Pediatrics Medicine Grodnok State Medicalm University, Republic of Belarus.

*Corresponding Author: Bon L.I., Candidate of Biological Science, associate professor of Chair of pathological physiology of the name of D.A. Maslakov, Education Establishment "Grodno State Medical University, Belarus.

Received date: November 11, 2021; Accepted date: December 02, 2021; Published date: January 04, 2022

Citation: Bon L.I., Maksimovich N.Ye., Dremza I.K. and Lychkovskaya Maria A (2022) Stepwise Cerebral Ischemia Causes Disturbances in Mitochondrial Respiration of Neurons in the Cerebral Cortex of Rats. J, Biotechnology and Bioprocessing 3(1); DOI: 10.31579/2766-2314/063

Copyright: (C) 2022, Bon L.I, This is an open access article distributed under the Creative Commons Attribution License, which permits unrestricted use, distribution, and reproduction in any medium, provided the original work is properly cited.

\section{Abstract}

Objectives. To conduct a comparative analysis of respiration of mitochondria of brain homogenates of rats with stepwise subtotal cerebral ischemia with different duration between ligations of both common carotid arteries.

Methods. The experiments were performed on 24 male mongrel white rats weighing $260 \pm 20 \mathrm{~g}$. Cerebral ischemia (CI) was simulated under intravenous thiopental anesthesia $(40-50 \mathrm{mg} / \mathrm{kg})$. The control group consisted of falsely operated rats of similar sex and weight. To study mitochondrial respiration, the brain was extracted in the cold $\left(0-4{ }^{\circ} \mathrm{C}\right)$, dried with filter paper, weighed and homogenized in an isolation medium containing $0.32 \mathrm{M}$ sucrose, $10 \mathrm{mM}$ Tris-HCl, $1 \mathrm{mM}$ EDTA, pH 7.4 (in a ratio of 1:10), using Potter-Evelheim homogenizer with Teflon pestle according to the modified method. To prevent systematic measurement errors, brain samples from the compared control and experimental groups of animals were studied under the same conditions.

Results. Stepwise SCI with an interval of 1 and 3 days between bandages of both OCA leads to damage to the neurons of the parietal cortex and hippocampus of rats, which manifests itself in a decrease in their size, deformation of the pericaryons, an increase in the number of shrunken neurons and shadow cells. The most pronounced changes were observed in the subgroup with an interval between dressings of 1 day. These changes were similar to the changes in SCI ( $>0.05)$, except for the absence of cells with pericellular edema in the hippocampus and a smaller number of them in the parietal cortex. SCI with an interval between WASP dressings of 7 days, on the contrary, it is manifested by less pronounced histological changes, especially in the hippocampus.

Conclusion. In cerebral ischemia, damage to the inner mitochondrial membrane occurs due to activation of free radical oxidation processes. Damage to the inner mitochondrial membrane, in turn, leads to an increase in its permeability and a decrease in the level of the proton gradient due to the transition of protons along the concentration gradient through the resulting nonspecific pores into the mitochondrial matrix. As a result, the efficiency of ATP synthesis decreases, and more substrates and oxygen are required to maintain the intermembrane potential under these conditions.

Key words: cerebral ischemia; mitochondria; brain homogenates

\section{Introduction}

Mitochondria play a key role in the life of the cell. Their most characteristic feature is the presence of a large number of enzymes involved in oxidative phosphorylation and energy supply to the cell [1-5]. In addition, mitochondria are involved in the storage and transmission of hereditary information, apoptosis and plastic processes [6-9]. 
The energy requirements of the brain, necessary for normal functional activity of neurons, are approximately $1046 \mathrm{~J}$ or 250 calories per minute, are provided by $95 \%$ due to aerobic glycolysis $[1,7,10-12]$. Due to the fact that the main way of obtaining energy in the brain is aerobic breakdown of glucose, its need for oxygen, in comparison with that of other organs, is extremely high $[14,15]$.

Most of the studies conducted are devoted to the study of the pathogenesis of cerebral ischemia [1, 16-18], while insufficient attention has been paid to the mechanisms of brain compensation.

When modeling severe forms of cerebral ischemia (total and one-stage subtotal), compensation mechanisms are absent due to the development of deep hypoxia $[1,16]$. The study of the activity of compensatory mechanisms is possible on the basis of assessing changes in energy exchange in rats with stepwise subtotal cerebral ischemia - alternate ligation of both common carotid arteries (CCA) with different time intervals between dressings.

The aim of this work is to carry out a comparative analysis of mitochondrial respiration of brain homogenates of rats with stepwise subtotal cerebral ischemia with different durations between ligations of both common carotid arteries.

\section{Methods}

The experiments were carried out on 24 male outbred white rats weighing $260 \pm 20 \mathrm{~g}$ in compliance with the Directive of the European Parliament and of the Council № 2010/63/EU of 22.09.2010 on the protection of animals used for scientific purposes.

Modeling of cerebral ischemia (CI) was carried out under conditions of intravenous thiopental anesthesia $(40-50 \mathrm{mg} / \mathrm{kg})$.
Graduated subtotal IHM (GSCI) was performed by sequential ligation of both CCA with an interval of 7 days (subgroup 1, $n=6$ ), 3 days (subgroup $2, n=6$ ) or 1 day (subgroup 3, $n=6$ ) [4]. The sampling of material was carried out 1 hour after ligation of the second CCA in each of the subgroups.

The control group consisted of sham-operated rats of the same sex and weight.

To study mitochondrial respiration, the brain was removed in the cold (0$4^{\circ} \mathrm{C}$ ), dried with filter paper, weighed and homogenized in an isolation medium containing $0.32 \mathrm{M}$ sucrose, $10 \mathrm{mM}$ Tris- $\mathrm{HCl}, 1 \mathrm{mM}$ EDTA, $\mathrm{pH}$ 7.4 (in the ratio 1:10) using a Potter-Evelheim homogenizer with a Teflon pestle according to a modified method $[19,20]$.

Mitochondria were isolated by differential centrifugation. The nuclear fraction was separated by centrifugation at $600 \mathrm{~g}$ for $10 \mathrm{~min}\left(4^{\circ} \mathrm{C}\right)$. The resulting supernatant was centrifuged at $8500 \mathrm{~g}$ for $10 \mathrm{~min}\left(4^{\circ} \mathrm{C}\right)$, the mitochondrial pellet was washed twice in the isolation medium and resuspended to a protein concentration of $35-40 \mathrm{mg} / \mathrm{ml}$ in the isolation medium and stored in a short tube on ice. Protein concentration was determined by the Lowry method [19].

To study mitochondrial respiration, a concentrated suspension of mitochondria was introduced into a thermostated sealed polarographic cell with a volume of $3.0 \mathrm{ml}$ with an incubation medium in an amount providing a final protein concentration in the cell of $1 \mathrm{mg} / \mathrm{ml}$. The incubation medium for recording mitochondrial respiration includes 0.17 $\mathrm{M}$ sucrose, $40 \mathrm{mM} \mathrm{KCl}, 10 \mathrm{mM}$ Tris- $\mathrm{HCl}, 5 \mathrm{mM} \mathrm{KH} 2 \mathrm{PO} 4,8 \mathrm{mM}$ KHCO3, 0.1 mM EDTA, pH 7.4.

The principle of operation of the polarographic cell is based on the registration of oxygen uptake by mitochondria using the built-in Clarke electrode at a temperature of $25^{\circ} \mathrm{C}$ (Figure 1).

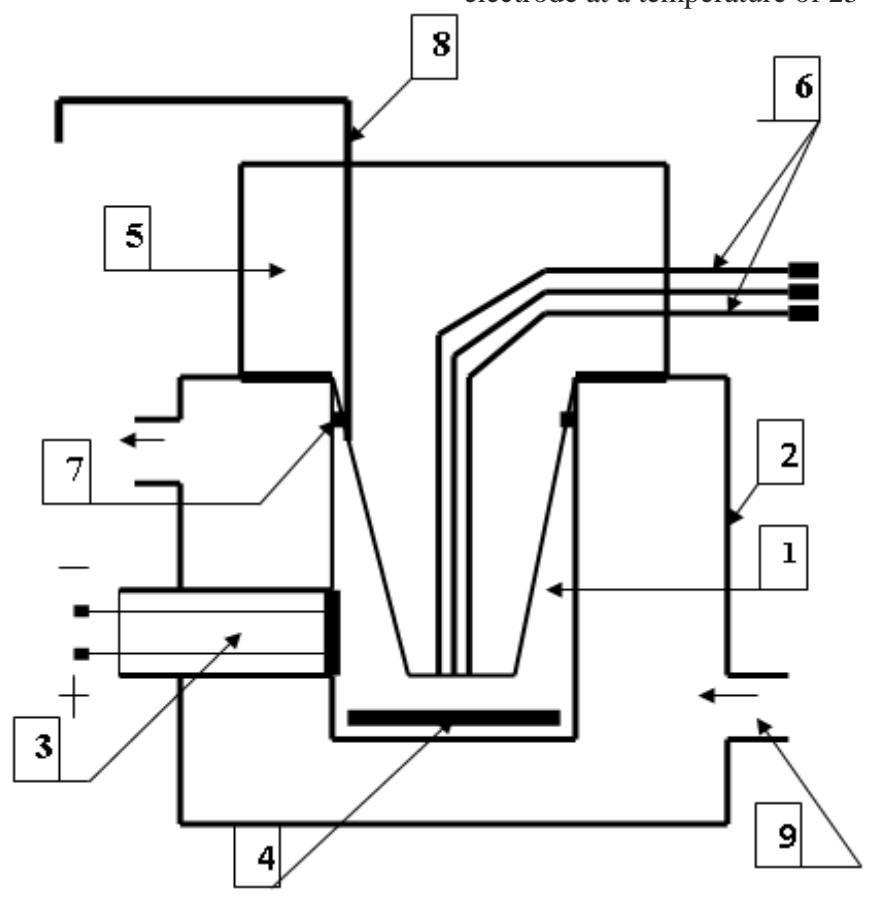

Figure 1 - Polarographic cell for studying the respiratory activity of mitochondria

1 - cell; 2 - thermostatically controlled chamber; 3 - Clarke electrode; 4 magnetic stirrer; 5 - sealing plug; 6 - channels for dosed anaerobic administration of substrates and ADP; 7 - a sealing ring; 8 - channel for removing air and excess liquid; 9 - fitting for connection to an ultrathermostat. 
Registration of changes in oxygen tension (pO2) in the mitochondrial suspension was carried out using an electronic recorder KSP-4.

The Clarke electrode was calibrated by sequentially blowing air (pO2 of air) and gaseous nitrogen ( $\mathrm{pO} 2=0 \mathrm{mmHg}$ ) through the cell.

After registering the rate of basal (endogenous) respiration in the absence of a substrate (V1), respiration substrates (malate - $2 \mathrm{mM} /$ glutamate - 5 $\mathrm{mM}$ or succinate $-5 \mathrm{mM}$ ) are alternately introduced into the mitochondrial suspension, and then ADP in an amount of $200 \mathrm{nmol} / \mathrm{ml}$. According to the obtained polarograms (Figure 3), the respiration rate of mitochondria in different metabolic states and the coefficients characterizing the conjugation of oxidation and phosphorylation processes are calculated.

The following parameters of mitochondrial respiration were recorded: V1 - basal respiration rate, V2 - substrate-dependent respiration rate, V3- respiration rate coupled with phosphorylation (after ADP addition), V4 respiration rate after completion of phosphorylation of added ADP. The parameters characterizing the conjugation of oxidation and phosphorylation processes in mitochondria were determined: the acceptor control coefficient $(\mathrm{AK}=\mathrm{V} 3 / \mathrm{V} 2)$, the respiratory control coefficient (DC $=\mathrm{V} 3 / \mathrm{V} 4)$ and the phosphorylation coefficient $-\mathrm{ADP} / \mathrm{O}$.

The use of solutions of substrates of succinate and malate / glutamate complex makes it possible to assess the degree of functional activity of the electron transfer chain (ETC) in mitochondria as a whole, in particular, of the I and II ETC complex.

To prevent systematic measurement errors, brain samples from the compared control and experimental groups of animals were studied under the same conditions.

\begin{tabular}{|c|c|c|c|c|c|c|c|c|}
\hline \multicolumn{2}{|c|}{ Group } & $\begin{array}{l}\mathrm{V1} \\
(\mathrm{ng} \text { at } \mathrm{O} / \\
\min \times \mathrm{mg} \\
\text { protein) }\end{array}$ & $\begin{array}{l}\mathrm{V} 2 \\
(\mathrm{ng} \text { at } \mathrm{O} / \\
\text { min } \times \mathrm{mg} \\
\text { protein })\end{array}$ & $\begin{array}{l}\mathrm{V3} \\
(\mathrm{ng} \text { at } \mathrm{O} / \mathrm{min} \\
\times \mathrm{mg} \text { protein) }\end{array}$ & $\begin{array}{l}\mathrm{V} 4 \\
(\mathrm{ng} \text { at } \mathrm{O} / \mathrm{min} \times \\
\text { mg protein) }\end{array}$ & $\begin{array}{l}(\mathrm{V} 3 / \mathrm{V} 2) \\
\text { acceptor control } \\
\text { coefficient }\end{array}$ & $\begin{array}{l}\text { (V3 / V4) } \\
\text { respiratory } \\
\text { control } \\
\text { coefficient }\end{array}$ & $\begin{array}{l}\text { ADP/O) } \\
\text { phosphorylat } \\
\text { ion } \\
\text { coefficient }\end{array}$ \\
\hline \multicolumn{9}{|c|}{ Malate/glutamate substrate } \\
\hline \multicolumn{2}{|c|}{ Control } & $\begin{array}{l}18 \\
(14 ; 19)\end{array}$ & $\begin{array}{l}27 \\
(26 ; 27)\end{array}$ & $\begin{array}{l}51 \\
(48 ; 56)\end{array}$ & $\begin{array}{l}31 \\
(27 ; 34)\end{array}$ & $\begin{array}{l}2,0 \\
(1,8,3,0)\end{array}$ & $\begin{array}{l}1,6 \\
(1,6 ; 1,7)\end{array}$ & $\begin{array}{l}2,0 \\
(1,9 ; 2,1)\end{array}$ \\
\hline \multirow[b]{3}{*}{ U } & $1 \mathrm{pg}$ & $\begin{array}{l}12 \\
(3 ; 18)\end{array}$ & $\begin{array}{l}51^{*} \\
(35 ; 63)\end{array}$ & $\begin{array}{l}46 \\
(38 ; 53)\end{array}$ & $\begin{array}{l}41 \\
(26 ; 51)\end{array}$ & $\begin{array}{l}2,9 \\
(2,2 ; 3,5)\end{array}$ & $\begin{array}{l}3,5^{*} \\
(3,0 ; 4,3)\end{array}$ & $\begin{array}{l}2,9 \\
(2,1 ; 3,0)\end{array}$ \\
\hline & $2 \mathrm{pg}$ & $\begin{array}{l}27 \\
(12 ; 34)\end{array}$ & $\begin{array}{l}21+ \\
(19 ; 22)\end{array}$ & $\begin{array}{l}42 \\
(26 ; 56)\end{array}$ & $\begin{array}{l}16 *+ \\
(13 ; 19)\end{array}$ & $\begin{array}{l}2,1 \\
(1,9 ; 2,4)\end{array}$ & $\begin{array}{l}2,1 \\
(1,3 ; 4,1)\end{array}$ & $\begin{array}{l}1,5+ \\
(1,3 ; 2,5)\end{array}$ \\
\hline & $3 \mathrm{pg}$ & $\begin{array}{l}12 \\
(9 ; 18)\end{array}$ & $\begin{array}{l}15^{*}+ \\
(7 ; 22)\end{array}$ & $\begin{array}{l}26 *+ \\
(17 ; 31)\end{array}$ & $\begin{array}{l}9 *+ \\
(8 ; 13)\end{array}$ & $\begin{array}{l}1,8 \\
(1,4 ; 2,2)\end{array}$ & $\begin{array}{l}1,7 \\
(1,3 ; 3,5)\end{array}$ & $\begin{array}{l}1,4 *+ \\
(1,3 ; 1,6)\end{array}$ \\
\hline \multicolumn{9}{|c|}{ Substrate "succinate" } \\
\hline \multicolumn{2}{|c|}{ Control } & $\begin{array}{l}17 \\
(15 ; 17)\end{array}$ & $\begin{array}{l}34 \\
(28 ; 36)\end{array}$ & $\begin{array}{l}66 \\
(65 ; 68)\end{array}$ & $\begin{array}{l}38 \\
(36 ; 40)\end{array}$ & $\begin{array}{l}2,0 \\
(1,9 ; 2,3)\end{array}$ & $\begin{array}{l}1,8 \\
(1,7 ; 1,9)\end{array}$ & $\begin{array}{l}1,9 \\
(1,8 ; 1,9)\end{array}$ \\
\hline \multirow[b]{3}{*}{ 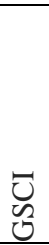 } & $1 \mathrm{pg}$ & $\begin{array}{l}31 * \\
(18 ; 35)\end{array}$ & $\begin{array}{l}40 \\
(31 ; 45)\end{array}$ & $\begin{array}{l}66 \\
(42 ; 68)\end{array}$ & $\begin{array}{l}69^{*} \\
(47 ; 84)\end{array}$ & $\begin{array}{l}2,8 \\
(2,3 ; 3,1)\end{array}$ & $\begin{array}{l}3,6 * \\
(2,4 ; 3,8)\end{array}$ & $\begin{array}{l}2,1 \\
(1,8 ; 3,4)\end{array}$ \\
\hline & $2 \mathrm{pg}$ & $\begin{array}{l}14 \\
(12 ; 24)\end{array}$ & $\begin{array}{l}13 *+ \\
(10 ; 19)\end{array}$ & $\begin{array}{l}33^{*} \\
(24 ; 44)\end{array}$ & $\begin{array}{l}26 *+ \\
(19 ; 27)\end{array}$ & $\begin{array}{l}2,8 \\
(2,0 ; 3,4)\end{array}$ & $\begin{array}{l}1,5+ \\
(1,3 ; 1,9)\end{array}$ & $\begin{array}{l}1,7 \\
(1,2 ; 1,9)\end{array}$ \\
\hline & $3 \mathrm{pg}$ & $\begin{array}{l}12+ \\
(9 ; 15)\end{array}$ & $\begin{array}{l}16 *+ \\
(12 ; 17)\end{array}$ & $\begin{array}{l}26 *+ \\
(23 ; 27)\end{array}$ & $\begin{array}{l}13^{*}+ \\
(9 ; 20)\end{array}$ & $\begin{array}{l}1,6+ \\
(1,5 ; 2,0)\end{array}$ & $\begin{array}{l}1,0 *+ \\
(1,0 ; 1,3)\end{array}$ & $\begin{array}{l}1,2 * \\
(1,1 ; 1,2)\end{array}$ \\
\hline
\end{tabular}

Note: $*$ - p $<0.05$ compared with the control group, $+-p<0.05$ compared with the 1 st subgroup of GSCI, GSCI - stepwise subtotal cerebral ischemia, sg - subgroup

Table 1 - Indicators of respiration of the mitochondrial fraction of brain homogenates of rats with stepwise subtotal cerebral ischemia when using substrates "malate / glutamate" and "succinate", Me (LQ; UQ)

As a result of research, quantitative continuous data were obtained. Since the experiment used small samples that had an abnormal distribution, the analysis was carried out using nonparametric statistics using the Statistica 10.0 licensed computer program for Windows (StatSoft, Inc., USA). Data are presented as Me (LQ; UQ), where Me - median, LQ - value of the lower quartile; UQ is the upper quartile value. Differences between groups were considered significant at $\mathrm{p}<0.05$ (Kruskell-Wallis test with Bonferoni's correction).

\section{Results}

Step SCI with an interval of 1 and 3 days between ligation of both CCA leads to damage to neurons in the parietal cortex and hippocampus of rats, which manifests itself in a decrease in their size, deformation of perikarions, and an increase in the number of shrunken neurons and shadow cells [1]. The most pronounced changes were observed in the subgroup with an interval between dressings of 1 day. These changes were similar to those in SCI ( $>$ > 0.05), except for the absence of cells with pericellular edema in the hippocampus and their smaller number in the parietal cortex. SCI with an interval between CCA dressings of 7 days, on the contrary, is manifested in a lesser severity of histological changes, especially in the hippocampus.

When studying the respiration of the mitochondrial fraction of brain homogenates of rats with stepped cerebral ischemia, the following data were obtained.

Compared with the "control" group, in the presence of malate / glutamate in the 1st subgroup of SCI, an increase in V2 was observed by 46 (39; $56) \%, p<0.05$ and the respiratory control ratio by $56(51 ; 63) \%$, p $<0.05$, indicating the activation of hydrogen proton transport through the ATP synthase complex. Other indicators did not change ( $p>0.05)$, table 1 . 


\section{Discussion}

In the presence of succinate in the 1st subgroup of SCI with an interval between ligation of both common carotid arteries of 7 days, there was an increase in V1, V4 by $45(39 ; 52) \%$, p<0.05 and by $47(37 ; 55) \%, \mathrm{p}<0.05$, respectively, the respiratory control coefficient - by $48(41 ; 56) \%, \mathrm{p}<0.05$.

There were no differences in the V1, V2, V3, V4 indices, respiratory control coefficients, acceptor control and phosphorylation when using different substrates $(p>0.05)$, which indicates the equivalence of the consequences of changes in both complexes (I and II) of electron transfer.

Compared with the "control" group, in the 2nd subgroup of SCI with an interval between dressings of 3 days, in the presence of the "malate / glutamate" substrate, only a decrease in V4 by $49(32 ; 54) \%$ was noted, p $<0.05$. Indicators V2 and V4 were less by $58(42 ; 69) \%, \mathrm{p}<0.05$, and the phosphorylation coefficient - by $50(41 ; 65) \%$, p <0.05. In the presence of succinate, there was a decrease in the rates V2, V3 and V4 by 61 (51; $69) \%, \mathrm{p}<0.05,48(40 ; 52) \%, \mathrm{p}<0.05$ and $30(28 ; 39) \%, \mathrm{p}<0.05$, respectively. Compared with the 1 st subgroup of SICI, in the 2nd subgroup there was a decrease in V2 - by $67(52 ; 74) \%, \mathrm{p}<0.05$, V4 - by $58(49 ; 68) \%, \mathrm{p}<0.05$ and respiratory control coefficient - by 60 (52; $74) \%, \mathrm{p}<0.05$.

In the 3rd subgroup of GSCI with a minimum interval between dressings of both CCA 1 day, compared with the control group in the presence of succinate, there was a decrease in the V2, V3 and V4 rates by 52 (43; $65) \%, \mathrm{p}<0.05,61(52 ; 69) \%, \mathrm{p}<0.05$ and $65(58 ; 71) \%, \mathrm{p}<0.05$, respectively. The respiratory control coefficient also decreased by 42 (37; $49) \%, \mathrm{p}<0.05$ and the phosphorylation coefficient by - $37(28 ; 45) \%$, p $<0.05$.

A decrease in the V2, V3, V4 indices and the coefficient of respiratory control in the 3rd subgroup of GSCI indicates damage to electron carriers in mitochondria and enzymes of the Krebs cycle, which, in turn, led to a decrease in energy production, as evidenced by a low phosphorylation coefficient.

Compared with the indicators in the 1st subgroup (the interval between CCA dressings is 7 days), in the 3rd subgroup of the CCA (the interval between the CCA dressings is 1 day), in the presence of the malate / glutamate substrate, the V2, V3 and V4 indicators decreased by 46 (34; $52) \%, \mathrm{p}<0.05,52(41 ; 64) \%, \mathrm{p}<0.05$ and $72(61 ; 82) \%, \mathrm{p}<0.05$, respectively. There was also a decrease in the phosphorylation coefficient by $30(19 ; 45) \%, \mathrm{p}<0.05$. Compared with the 1 st subgroup of GSCI, the velocities V2, V3 and V4 were $71(63 ; 84) \%$ less, p <0.05; by 43 (38; $51) \%, \mathrm{p}<0.05$ and $79(67 ; 86) \%, \mathrm{p}<0.05$, respectively, and the phosphorylation coefficient - by $50(41 ; 65) \%$, p <0.05 ... In the presence of succinate, there was a decrease in the rates V1, V2, V3 by $57(49 ; 68) \%$, $\mathrm{p}<0.05$ and V4 by $80(71 ; 95) \%, \mathrm{p}<0.05$ and $66(52 ; 74) \%, \mathrm{p}<0.05$. The coefficients of acceptor control also decreased - by $43(39 ; 48) \%$, p <0.05, respiratory control - by $72(62 ; 83) \%, \mathrm{p}<0.05$ and the phosphorylation coefficient - by $43(29 ; 54) \%, \mathrm{p}<0.05$.

Compared with the 2 nd subgroup, in the 3 rd subgroup of the GSCI, in the presence of both substrates used, the respiration indices of the mitochondrial fraction of brain homogenates did not change significantly ( $>$ > 0.05), which indicates the equivalence of violations of I and II electron transfer complexes in 2nd and 3rd subgroups of GSCI.

One of the leading pathogenetic mechanisms of ischemic brain damage is a dysfunction of complex I (NADH-dehydrogenase complex) in conditions of oxygen deficiency, a decrease in NADH oxidation and inhibition of the Krebs cycle.

With cerebral ischemia, damage to the inner mitochondrial membrane occurs due to the activation of free radical oxidation processes. Damage to the inner mitochondrial membrane, in turn, leads to an increase in its permeability and a decrease in the level of the proton gradient due to the transition of protons along the concentration gradient through the formed nonspecific pores into the mitochondrial matrix. As a result, the efficiency of ATP synthesis decreases, and more substrates and oxygen are required to maintain the intermembrane potential under these conditions.

As shown earlier, with ligation of both CCA with an interval of 3 days, the histological changes were not as pronounced as in subgroup 3 - no cells with pericellular edema were observed. When bandaging with an interval of 7 days, the pathological changes were even less: the ratio of neurons according to the degree of chromatophilia of the cytoplasm and the size of the perikaryons of neurons differed insignificantly from the values of the indicator in the control group.

In the same animals, the respiration parameters of the mitochondrial fraction of brain homogenates normalized, and some even exceeded the control level, which may be associated with the launch of a number of compensatory processes: an increase in the synthesis of cytochromes, enzymes of the Krebs cycle, the formation of mitochondria, restoration of their cristae, and an increase in the efficiency of oxygen utilization processes. and oxidation substrates and their delivery to mitochondria, due to morphofunctional changes, rearrangement of mitochondrial enzyme complexes, activation of oxidation and phosphorylation enzymes, an increase in the degree of conjugation of oxidation and phosphorylation of adenine nucleotides (ADP, AMP, creatine), activation of the glycolytic nucleic acid pathway, and an increase in the synthesis of proteins, transport of $\mathrm{O} 2$ and metabolic substrates, as well as the economical use of oxygen and metabolic substrates in biological oxidation reactions and plastic processes, increasing the efficiency of anaerobic resis ATP synthesis and the activity of anabolic processes $[1,17,18,20]$.

\section{Conclusion}

Thus, the studies carried out have shown the dependence of the severity of brain damage in GSCI on the interval between the cessation of blood flow in both CCA. With a 7-day interval between CCA dressings, compensatory mechanisms were activated [20], which prevented the development of significant disorders of energy exchange, leading to less pronounced morphological disorders and the degree of neurological deficit [22].

When the CCA was ligated with an interval of 1 day, the degree of impairment of energy exchange was maximum, which indicates the lack of implementation of compensatory mechanisms.

\section{Acknowledgments}

Conflict of interest statement

The authors declare no conflict of interest.

\section{Funding sources}

State scientific program «To study the processes of damage and adaptation of the brain during its ischemia and the use of correction». 


\section{References}

1. Baertling F. (2018) NDUFA9 point mutations cause a variable mitochondrial complex I assembly defect. Clinical Genet 93. 111-118.

2. Hackenbrock C.R. (1981) Lateral diffusion and electron transfer in the mitochondrial inner membrane. Trends Biochemistry. 15. 151-154.

3. Hoffmann C. (2018) The effect of differentiation and TGFß on mitochondrial respiration and mitochondrial enzyme abundance in cultured primary human skeletal muscle cells. Science Report. 8. 737-740.

4. Holvoet P. (2017) Low Cytochrome Oxidase 1 Links Mitochondrial Dysfunction to Atherosclerosis in Mice and Pigs. PLoS One. 12. 307-312.

5. Klinyerberg M. (1985) Principles of carrier catalysis elucidated by comparing two similar membrane translocators from mitochondria, the ADP/ATP carrier and the uncoupling protein. New York Academic Science. 456. 279-288.

6. Bon, E.I. (2020) Morphology of rat brain neurons in subtotal ischaemia and introduction of L-NAME and omega-3 polyunsaturated fatty acids L. I. Bon, N. E. Maksimovich, S. M. Zimatkin. Journal of Medical Science. C. 1-8.

7. Boumans H., Grivell L.A., Berden J.A. (1998) The respiratory chain in yeast behaves as a single functional unit. J. Biol. Chem. 273. 4872-4877.

8. Chalmers, G. R. (1992) Adaptability of the oxidative capacity of motoneurons / G. R. Chalmers, R. R., Roy, V. R. Edgerton. Brain. Res. 570 (1-2). P. 1-10.

9. Maksimovich N.Ye. (2019) Structural and functional features of mitochondria and methods of their study in experiment / N.Ye. Maksimovich, L.I. Bon, I.K. Dremza. MEDICUS. 5 P. 8-18.

10. Brand M.D., Murphy M.P. (1987) Control of electron flux through the respiratory chain in mitochondria and cells. Biological Review. 62. 141-193.
11. Casey R.P. (1984) Membrane reconstruction of the energyconserving enzymes of oxidative phosphorylation. Biochemistry Acta. 768. 319-347.

12. Prince R.C. (1988) The proton pump of cytochrome oxidase. Trends Biochemistry Science. 13. 159-160.

13. Srere P.A. (1982) The structure of the mitochondrial inner membrane-matrix compartment. Trends Biochemistry Science. 7. 375-378.

14. Leonard K., Haiker H., Weiss H. (1987) Three-dimensional structure of NADH: ubiquinone reductase (complex I) from Neurospora mitochondria determined by electron microscopy of membrane crystals. Molecular Biology. 194. 277-286.

15. MacFarlane, D. E. (1975) The effects of ATP on plateles. Evidence against the central role of released ADP in primary aggregation. Blood. №46. - P. 309.]

16. Bon, E.I. (2021) Evaluation of neurological deficiency in rats with cerebral ischemia following the administration of omega polyunsaturated fatty acids. Journal of Medical Science. V. 90(3) - P. 137-143.

17. Chan, P.H. (2004) Mitochondria and neuronal death/survival signaling pathways in cerebral ischemia. Neurochem. Res.Vol. 29. - P. 1943-1949.

18. Clemens, J. A. (2000) Cerebral ischemia: gene activation, neuronal injury, and the protective role of antioxidants. Free Radic. Biol. Med. Vol. 28. - P. 1526-1531.

19. Bon, L.I. (2021) Histological disorders of neurons of phylogenetically different parts of the cerebral cortex in partial, subtotal, stepwise subtotal, and total cerebral ischemia. . Journal of Medical Science. V. 90(1) - P. 108-115.

20. LaManna, J. C. (1992) Brain adaptation to chronic hypobaric hypoxia in rats. J. Appl. Physiol. Vol. 72. - P. 2238-2243.

21. DePierre J.W., Ernster L. (1988) Enzyme topology of intracellular membranes. Review Biochemistry. 46. 201-261.
This work is licensed under Creative Commons Attribution 4.0 License
Submit Manuscript
To Submit Your Article Click Here:

DOI: $10.31579 / 2766-2314 / 063$
Ready to submit your research? Choose Auctores and benefit from:

$>$ fast, convenient online submission

$>$ rigorous peer review by experienced research in your field

$>$ rapid publication on acceptance

$>$ authors retain copyrights

$>$ unique DOI for all articles

$>$ immediate, unrestricted online access

At Auctores, research is always in progress.

Learn more https://auctoresonline.org/journals/biotechnology-andbioprocessing- 